\title{
CONSTRUCTION PROJECT DELIVERY IN A DEREGULATED ECONOMY
}

\author{
Ajaelu C. Henry \\ Department of Urban and Regional Planning, \\ Enugu University of Science \& Technology, Nigeria
}

\author{
Reuben A. Okereke \\ Department of Quantity Surveying \\ Imo State University, Owerri, Nigeria.
}

Abstract - Construction projects located in Nigeria suffer from many problems and complex issues and this ultimately impact on the country's economic development. Consequently, the aim of this paper is to assess the Role of Quality Surveyor in Construction Project Delivery in a Deregulated Economy. The specific objectives of the study are to examine the effect of deregulating of materials specification as stated in bill of quantities (BOQ) on building construction project delivery in Nigeria. Literature review was carry out in the study. The methodology adopts was focused group discussion (FGDs) method. The study explores both primary and secondary sources of data collection. Primary data were collected mainly through in-depth interview and Focused Group Discussions (FGDs). The populations of the study involve 20 interviewed respondents and 5 FGDs participants. The interview was carry out on contractors and foremen on construction site while the FGDs were conducted in two sessions. Each session featured five (5) participants in an intensive deliberation on the subjects of study, with the researcher providing the lead. The method of analysis employed was qualitative descriptive. The qualitative element enables the researcher to utilized focus group discussion analysis with involved arguments points. The researcher constructed a conceptual model map, with its target Group Argument Discussion (GAD). The model representing the effect of quantity surveyor (QS) deregulated on material specification as showed in bill of quantities contract document on time and cost. The argument discussion revealed that if the government put their house in order by implementing the policies on regulating construction project, it will save the country from financially loss resulting from delay in project delivery and high rate of collapse building. It concluded that the current policy and regulation in the country is only on paper. Therefore, it recommends that the Federal Government of Nigeria should see to the effective adherence to the regulation so as to improve efficiency of construction project delivery.

Keywords - Construction, Project, Delivery, Economy

\section{INTRODUCTION}

The importance of good structures (building, road etc.) in the society has necessitated the need for improvements in the standard of construction, this is possible through coordinated and committed participation of all stakeholders in the industry using the appropriate regulations as the key guide and document for quality management. However, there has been increase in cases of building collapse in Nigeria in recent times, which has brought to the fore the effectiveness of instituted construction regulations by Ruya, Chitumu, and Jatau, (2017) ${ }^{1}$.

Policies and procedural frameworks are regulations guiding the building industry. These rules and regulations include Environmental Laws; Health and Safety; Environmental Impact Assessment; Approval Processes of Awarding of Contract and Payment; Construction and Other Ethical Practices by Usman, Kamau, and Mireri, (2014) ${ }^{2}$. These ethical standards are used in enhancing construction project delivery in an economy. These are laid down rules and regulations guiding the various stake holders on project delivery within the construction industry.

Regulation of building construction in Nigeria is done through a statutory authority known as the Council of Registered Builders of Nigeria - CORBON, whose function is to establish and oversee the construction industry and coordinate its development. The Council of Registered Builders of Nigeria - CORBON is mandated to encourage the standardization and improvement of construction techniques and materials, provide, promote, review and co-ordinate training programs for skilled construction workers and construction site supervisors, accredit and register contractors and regulate their professional undertakings, accredit and certify skilled construction workers and construction site supervisors, develop and publish a code of conduct for the construction industry.

Policy/procedural frameworks are laws governing the construction industry to successful project delivery. In developed economies, building laws, regulations and codes are established for use in the building industry. For example, UK has professional and regulating bodies, research institutions as well as effective utilization of their tertiary institutions to ensure the production of buildings and proper management at every stage by Jambol, $(2012)^{3}$. 


\section{International Journal of Engineering Applied Sciences and Technology, 2020 \\ Vol. 5, Issue 1, ISSN No. 2455-2143, Pages 61-66 \\ Published Online May 2020 in IJEAST (http://www.ijeast.com)}

In a study by Ofori, $(2014)^{16}$, USA developed building legislation from a Uniform Building Code (UBC) to the Standard Building Code (SBC) and to International Building Code (IBC). The UK and American legislation promotes good building practice just like other developed economy but in developing economy there are no standard rule and guideline governing construction industry. The few that have are poorly monitored/deregulated as Usman et al (2014) $)^{2}$ points that in Nigeria, policies are there but lack of compliance is what's happening in practice by Jambol, (2012) ${ }^{3}$ said that Nigeria have National Building Code (NBC) that provided policies and procedures for building construction processes. However, the same person by Jambol, (2012) ${ }^{3}$ lamented that the Nigerian Building Industry (NBI) is fragmented, underperforming, uncoordinated, undisciplined and operating as if there are no laws guiding its operations. These are serious threats to project delivery within the building industry.

In spite of the laws guiding the NBI, the Nigeria construction industry is still characterized with the problem of substandard materials and workmanship; and can be controlled by proper use of the appropriate regulations by Umeokafor, Umeadi, \& Jones, $(2014)^{4}$. This is a serious bone of contention that influences cost, time and quality standards which affect project delivery. The Quantity Surveyors as key personnel that control materials specification and labor supplied need to put it hand in the right place if construction project has to be delivery to standard. As materials have to be certified before they're use on site; and each level of the building processes, must be inspected and approved by them.

\section{A. Aim and Objectives of the Study}

The aim of this study is to assess the role of Quality Surveyor in Construction Project Delivery in a Deregulated Economy.

\section{B. Objectives of the Study}

The objectives of the study were:

1. To examine the effect of deregulating of materials specification as stated in bill of quantities (BOQ) on building construction project delivery in Nigeria.

2. To examine the effectiveness of quantity surveyors body (NIQS) in regulating construction project in Nigeria.

3. To analyze the problems associated with construction standard and regulations in Nigeria.

\section{Research Questions}

1. What is the level of regulating of material specification as stated in bill of quantities (BOQ) in construction standard in Nigeria?

2. What is the effectiveness of quantity surveyor body (NIQS) in regulating construction project in Nigeria?

3. What are the problems associated with construction standard and regulations in Nigeria?

\section{Hypothesis}

$\mathrm{H}_{1}$ : There is significant relationship between regulated and deregulated materials specification on building construction project delivery in an economy.

$\mathrm{H}_{1}$ : There is no significant relationship between construction standard and instituted regulations in Nigeria.II. Proposed Algorithm

\section{LITERATURE REVIEW}

Construction regulations are statutory instruments that seek to ensure that the construction policies set out in the relevant legislation are carried out. Construction regulations approval is required for most construction work in any given country. In construction, regulation involves registration of contractors, projects, skilled construction workers, construction site supervisors, training institutions, and provisions relating to collection and payment of the construction levy.

Regulations are often not complied within quality control of materials and work on site Baake, Kamecke, \& Wey, (2007) ${ }^{5}$. Ayuba, Olagunju, and Akande, $(2011)^{6}$, categorized the problems in practice into two broad groups - unsound regulations and unused regulations. Unsound regulations arise because regulations are often not well-written. Unused regulations refer to problems that arise when specified products/services are not used. The causes of unsound regulations, according to Ayuba, et al (2011) ${ }^{6}$ are misuse or misquoting of standards, non-compliance with regulations, pseudo-specifications (more content than needed and not job specific) and conflict with drawings; unsound regulations are those that are unused by contractors and unused by contract administrators or construction enforcement officers.

\section{A. Regulatory Framework and Construction Standard}

Regulation is treated as synonymous with law. Regulations are rules or norms adopted by government and backed up by some threat or consequences, usually negative ones in the form of penalties. While a regulatory framework on the other hand, refers to a system of regulations and the means used to enforce them. These are usually established by industry regulatory bodies to regulate the specific activities Edinburgh, (2003) 7 . According to the Nigerian Institute of Quantity Surveyors (NIQS), regulatory framework is the due process of regulation surrounding a single topic that entails all of the relevant legislative documents (acts, regulations, annexes) and describes the agency or body responsible for administering the framework.

The Building Regulation finds it necessary to identify the factors that promote and determine the future regulation process of the building and regulation process and associated standards and guidance in the next 20 years in relation to sustainable construction issues Architect and Quantity Surveyors Act, (2010) quoted in Ruya, (2017) ${ }^{1}$. The factors are based on emerging scenarios relating to physical, social and economic changes that are taking place in the country and globally like international requirements, human needs and 


\section{International Journal of Engineering Applied Sciences and Technology, 2020 \\ Vol. 5, Issue 1, ISSN No. 2455-2143, Pages 61-66 \\ Published Online May 2020 in IJEAST (http://www.ijeast.com)}

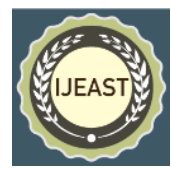

responsibilities and technological changes. Edinburgh (2003) ${ }^{7}$ indicated that some of the factors include climate changes, resource conservation, waste minimization, biodiversity and health and well-being of individuals and communities in and around building. The relationship between construction practices and regulations and a variety of economic growth, environmental quality and social prosperity factors is increasingly being recognized globally Christensen, $(2009)^{8}$.

The Current Regulatory Framework in developing countries like Nigeria results in conflicts due to inadequacy at the boundaries of the responsibilities of its composite agencies and inevitably policy and development aspirations. An ideal situation may be unachievable, but few would argue that no improvement is possible. The sustainable development agenda in particular has already brought many important issues and conflicts to the fore particular in respect of planning, land use and construction activities Ruya, (2017) ${ }^{1}$. The effectiveness of the current regulatory frameworks in Nigeria are therefore of uppermost importance in building standard in the construction sector.

\section{A. Some Specialized Regulatory Boards in Nigerian Construction Sector:}

\section{Quantity Surveyors Registration Board of Nigeria (QSRBN)}

Is the regulatory body of the quantity surveying profession and practice in Nigeria? It was established by Decree No. 31 of December 5, 1986, now CAP 383 Laws of the Federation of Nigeria (LFN). It goals includes:

- $\quad$ To ensure that all quantity surveying graduates produced by higher institutions of learning in Nigeria meet internationally required standards.

- To eliminate quackery and ensure that all Quantity Surveyors employed in both the private and public sectors are registered with QSRBN.

- $\quad$ To ensure that firms carrying out quantity surveying services in the country are registered with the Board and adhere strictly to the best practices and code of conduct of the profession.

The body executes its mandate through training, registration and enhancement of ethical practice. According to the regulations, no person should practice under any name, title or style containing any of the words or phrases "quantity surveyor" or "quantity surveying" unless he is registered under the Law as a Quantity Surveyor.

\section{The Society of Chartered Surveyors (2006)}

Identifies that upholding ethical principles is a key reason why people rely on professional bodies. Competence and trust are central elements in generating confidence in the professions by The Society of Chartered Surveyors, (2006); Cartlidge $(2011)^{9}$ argues that professions can only survive if the public retains confidence in them. Transparency and ethical behaviour are particularly important for quantity surveyors who are involved daily with financial transactions such as procurement, contractual arrangements, payments and valuations by Cartlidg, (2011) .

\section{Nema and Construction Standard}

The National Environment Management Authority (NEMA) is a body established under the Environmental Management Act of the laws of Nigeria to exercise general supervision and coordination over all matters relating to the environment and to be the principal instrument of Government in the implementation of all policies relating to the environment. NEMA has the primary responsibility of implementing environmental safeguards, although many actors have responsibilities including civil society, private consulting firms, development banks which finance infrastructure and other government actors including local government and the court system. Currently, the system suffers from inadequate funding, corruption, a lack of engagement with important community stakeholders, gaps or duplications of regulations, and a misunderstanding by society at-large of the benefits of a sustainable and standard construction. These serious issues result in little oversight of development projects with potentially huge environmental impacts.

\section{B. Impacts of Policy/Procedural Frameworks}

Policy and procedural framework is a means of avoiding the ills inherent in the construction sector and which lead to project failure, incompletion, and abandonment by Idoro, $(2014)^{10}$. However, the success of any building project in public or private sectors depends on the level of compliance to policies/procedures and control, and strict monitoring of time, cost, material, quality and environmental constraints by Aniekwu, $(2003)^{11}$.

Policy/procedural frameworks are supposed to be the guiding principles for building production within the built environment; unfortunately, government officials do not follow standards of town planning provisions, thereby allocating plots without following rules and procedures by Ede, $(2010)^{12}$. This was in agreement with by Ike $(2012)^{13}$, that town planning departments were no longer performing their role as laid down by law. Contrary in Dubai, studies have shown that before any project starts, specialized property development consultants are engaged by Ike, (2012) ${ }^{13}$; Ede, $(2010)^{12}$. These consultants study the soil and conducts investigation. The design carried out based on the reports of the soil investigations by Usman, Chen, and Lodson, $\left(2010^{14}\right.$ points that in Nigeria, policies are there but lack of compliance is what's happening in practice.

For instance, in Dubai, it takes eight months for a building plan to be approved by Ike, $(2012)^{13}$. He added that contractors are not allowed to mobilize to site until after the approval processes. Besides, materials have to be certified by a consultant before they're use on site; and each level of the building processes, must be inspected and approved. With these, government and professional bodies track and monitor building production from the initial to completion phases. 


\section{International Journal of Engineering Applied Sciences and Technology, 2020 \\ Vol. 5, Issue 1, ISSN No. 2455-2143, Pages 61-66 \\ Published Online May 2020 in IJEAST (http://www.ijeast.com)}

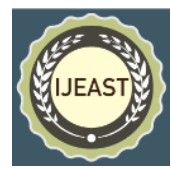

In spite of the laws guiding the NBI, the problem substandard materials and lack of compliance have continued on the increase by Idoro, $(2012)^{10}$. This is a serious bone of contention that influences cost, time and quality standards which affect project delivery. It is interesting to note that both civilian and military administrations have made the issue housing for all (new or improved) a policy or programme that was workable but unfortunate the implementation was not impressing. Poor management and delays of projects have led to indigenous contractors suffer.

Project compliance can be used to mean the whole process of translating broad policy and procedures and specific programmes of action that can enhance project delivery. This forms the interaction between the setting of goals and the actions required to achieve them. However well formulated a policy, unless action is taken to implement it, it remains only as paper work. Adherence to policy and procedures is the full range of managerial activities associated with putting the chosen strategy into place, supervision of its pursuit, and achieving the targeted result by Idoro, $(2012)^{10}$.

However, if there is no commitment from the organization's leaders to implement policies and procedures to achieving quality, any effort to actualize it can lead to cynicism and lessen the likelihood of its adoption and success in future. Proper compliance results from administrative decisions on how to do things and create fits between management policies and operations by Kabir, Bello, Kolo and Bustani, (2009) ${ }^{15}$; Idoro, (2012) ${ }^{10}$ opined that administrative and managerial elements are necessary to put a management policy into place and that full implementation can take several months to years depending on the amount of coordination involved.

\section{Government Influence in enabling the Construction Industry}

Government has great influence in simplification and standardization construction industry as they have fundamental power in:

\section{- Enabling a continuous flow of work}

Only the government can promote a sustained effort to ensuring a steadier and forecast-able flow of work suitable for various categories of small and emerging businesses. It is possible to extract information on the amount and types of work suitable for various categories of small and emerging businesses, and to direct these opportunities through applicable procurement mechanisms and foster greater participation of indigenous capacities. This initiative will also encourage private sector investment in the construction industry.

\section{- Access to finance}

The difficulties in securing credit for construction projects on reasonable terms from Lending Institutions, especially for interim construction financing, is identified as a very important problem of the Nigerian construction industry. A prerequisite for improved access to finance, is the regularization of this market to reduce the uncertainly which informs the investment decisions of financial institutions. Various programmes have been suggested to encourage the banks to establish specific loan-assistance programmes for emerging businesses but only the government can promote and sustain such programmes. Even access to a loanguarantee fund can be established for encouraging emerging construction businesses. In addition, mechanisms can be worked out to enable SMEs to cede contract payments to financial institutions until their loans are repaid.

\section{- Payment and surety arrangements}

Sureties or performance guarantees for certain low-risk publicsector contractors could be waived by government. However, these facilities will only be accorded to enterprises with a demonstrable capacity to perform. Registration and accreditation procedures, as well as performance monitoring, will minimize and limit risk in such cases cash.

\section{- Skills formation and access to training}

Access by emerging contractors to requisite construction skills is tied to reorientation of the structure and funding of industry training, in co-operation with industry stakeholders. The government through her appropriate agencies should promote the principle of equitable and manageable payment towards training costs and the ability of contractors to access both artisan and entrepreneurial skills training through the auspices of a Sectorial education and training Authority. Generally, most small and emerging construction businesses are run by persons who may or may not have vocational training experience but are unlikely to have received any formal management training. Training schemes directed at enterprise owners and managers should be encouraged.

\section{METHODOLOGY}

The study adopts a focused group discussion method. The study explores both primary and secondary sources of data collection. Primary data were collected mainly through indepth interview and Focused Group Discussions (FGDs). The interview was carry out on contractors and foremen on construction site while the FGDs were conducted in two sessions. Each session featured five (5) participants in an intensive deliberation on the subjects of study, with the researcher providing the lead. The study conducted interviews with twenty people, eight contractors and twelve foremen.

Secondary data were, however, collected through data retrieval technique from relevant scholarly textbooks, journals, official publications, seminar and conference papers, newspapers and the Internet provided other sources of secondary data.

\section{A. Target Population}

Target population as described by Borg and Grall (2009) is a universal set of study of all members of real or hypothetical set of people, events or objects to which an investigator wishes to generalize the result. The target construction project 


\section{International Journal of Engineering Applied Sciences and Technology, 2020 \\ Vol. 5, Issue 1, ISSN No. 2455-2143, Pages 61-66 \\ Published Online May 2020 in IJEAST (http://www.ijeast.com)}

population of this study was five government building construction project in Enugu State while the study population was Consultants, Client, Contractors, Services Engineer/Project Manager, Architect, Civil/Structural, Mechanical etc.

Therefore, populations of the study involve 20 interviewed respondents and 5 FGDs participants were constituted through purposeful sampling procedure. Apart from its ease of administration, purposeful sampling helps to include identified key informants in the sample population.

\section{B. Sample and Sampling Technique}

Sample is a small group of elements or subjects drawn from the specified population of study. In other words, it is the actual number or part of a study population that is objectively and systematically selected for the study. Moreover, we sample because the entire population cannot be studied. To determine the sample size of the above estimated population of 20 and 5 participations, Taro Yamane formula or any other statistical method was not employed because of the small number of the population.

\section{Method of Data Analysis}

The study adopts qualitative descriptive methods of analysis. The qualitative element enables the researcher utilized focus group discussion analysis with involved discussion and arguments points.

\section{Discussion}

To analysis the objectives of this study, the researcher formulated operational and conceptual models for the study as shows below.

\section{- Operationalization of Model Variables}

The study will make use of two groups of variables in this study, the dependent variable and the independent variable.

Dependent variables for the study are

- Construction project deregulated

Independent variables are

- Material specification in BOQ,

- Cost

- Time

\section{E. Conceptual Model for Focus Group Discussion}

The model is a map for Group Argument Discussion (GAD). Thus, the conceptual model is showed below, the right hand side shows a construction project with deregulated materials as stated in bill of quantities (BOQ) while the left hand side shows a construction project with regulated materials as stated in the contract document. The central shows the Quantity Surveyor standing to control cost and time. At the end, the graph pointed that if one decided to move either right or left it will end in cost.

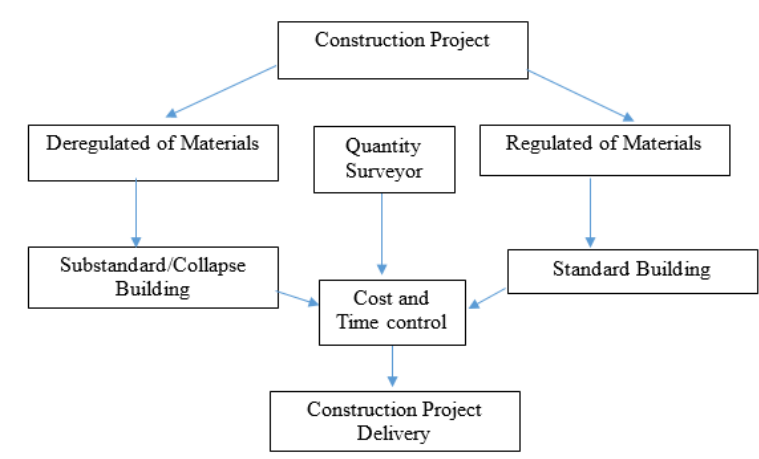

Fig 1: Researcher's Conceptual Model for GAD, (2019).

Therefore, the researcher found out that if a clients decided to carry out his construction project without involving the Quantity Surveyor (QS) whose major duty is acting as the accounting auditor and purchasing officers in a construction site to regulate his building construction project will end up wasting cost and time.

The focused group was of the opinion that if the government put their house in order by implementing the policies on regulating construction project as it will save the country from high rate collapse building and financially loss resulting from delay of project delivery by Ayuba, Olagunju, and Akande, $(2011)^{6}$.

The focused group had this to say on the issue of Regulatory Boards in Nigerian. They stated that professional bodies like Quantity Surveyors Registration Board of Nigeria (QSRBN), National Environment Management Authority (NEMA), etc are not carrying out their task effectively and efficiently.

Accordingly, the focused group discussants conclude that immunity clause in the Nigerian constitution is an irritant as it covers or protects Nigerian leaders (political) and government officials who commit financial crime especially that made for construction project.

\section{CONCLUSION AND RECOMMENDATIONS}

Policy and procedural is successful use in developed economy but its use in Nigeria has a break borne. It led to many questions: Is policy framework being applied only by a section of industry in Nigeria or by entire? Is policy framework seen by industry players as an effective tool that will ensure quality and durability in the building industry? Is there resistance to the application of policy/procedural framework by the industry? These posed a serious challenge in the delivery of projects on quality, cost and time overruns; however, these challenges can be mitigated by compliance and adherence to professional ethics within the building industry in developing countries.

The measuring tool for construction project delivery are cost, time and quality standards this is because clients usually demand for a better value on investments. As such, they want projects to be completed on time, within cost and with the 


\section{International Journal of Engineering Applied Sciences and Technology, 2020 \\ Vol. 5, Issue 1, ISSN No. 2455-2143, Pages 61-66 \\ Published Online May 2020 in IJEAST (http://www.ijeast.com)}

right quality. The above cannot be achieved if construction project is not regulated in an economy as the focus group discussion (FGD) participation stated that most of the projects in the country were completed at a higher cost and time overrun. Therefore, the researcher concluded that the current policy and regulation in the country is only on paper.

\section{RECOMMENDATIONS}

Base on the above, it recommended that:

1. Construction companies should always make use of regulations since unused regulation has a negative effect on the product and service of the construction companies in Nigeria

2. The Federal Government of Nigeria should see to the effective adherence to the regulation so as to improve the efficiency of the construction company in the government parastatals.

3. professional bodies should ensure capacity building in order to improve competencies within the built environment

4. erring professionals should be punished for unethical practices

5. Government and professional bodies should improve sensitization outlets to enable client's patronized qualified professionals

6. Government and professional bodies should set up a mechanism for law enforcement within the building industry.

\section{REFERENCES}

[1] Ruya, F., Chitumu, D., and Jatau, S. (2017). Construction Standard and Regulation in Nigeria. FIG Working Week 2017. Surveying the world of tomorrow - From digitalisation to augmented reality Helsinki, Finland, May 29-June 2, 2017.

[2] Usman, N. D., Kamau, P. K. and Mireri, C. (2014) The Impact of Policy and Procedural Framework on Project Performance Within the Building Industry in Abuja, Nigeria. International Journal of Engineering Research \& Technology (IJERT), 3(5) 2086-2092.

[3] Jambol, D. D. (2012). Building collapses phenomenon: Sanctions, Liabilities and Legal Implications. Proceedings of National Technical Workshop on Building collapse in Nigeria, National Building and Road Research Institute (NBRRI), pp. 83-105.

[4] Umeokafor, N., Umeadi, B. \& Jones, K. (2014). Compliance with occupational safety and health regulations: a review of Nigeria's construction industry
[5] Baake, P., Kamecke, U., \& Wey, C. (2007). A regulatory framework for new and emerging markets. Available at SSRN 978730.

[6] Ayuba, P., Olagunju, R. and Akande, O. (2011) Failure and Collapse of Buildings in Nigeria: Roles of Professionals and Other Participants in the Building Industry. Interdisciplinary Journal of Contemporary Research in Business, 4, 1267-1272.

[7] Edinburgh, G. (2003). Sustainable Construction and the Regulatory Framework Summary Report. University of Dundee, Scotland.

[8] Christensen, I. (2009). Sustainable Construction Policies in EPA Region IV. Practice Guide \#24 Spring 2009. Centre for Environmental Policy and Management, University of Louisville, West Bloom Street.

[9] Cartlidge, D. (2011). New Aspects of Quantity Surveying Practice, Spon Press, London.

[10] Idoro, G. I. (2012). Influence of Project plans on the outcome of construction projects procured by DesignBuild in Nigeria. Journal of Construction in Developing Countries, 17 (2) 77-99.

[11] Aniekwu (2003) Government Role in Developing the Construction Industry In Nigeria. Journal of Civil Engineering Department, University of Benin, Benin City, Nigeria. 40(2).

[12] Ede, A. N. (2010). Building collapses in Nigeria: The trend os casualities in the last decade (2000-2010). International Journal of Civil and Environmental Engineering, IJCEE/IJENS, 10(6).

[13] Ike, A. C. (2012). Case histories of auditing collapses in Nigeria. Proceedings of National Technical Workshop on Building collapses in Nigeria, Nigerian Building and Road Research Institute (NIBRRI), pp. 41-57.

[14] Usman, N. D., Chen, J. A. and Lodson, J. Y. (2010). Environmental Sciences and the Challenges of collapse buildings in Nigeria. Journal of Environmental Sciences and Agriculture in Developing Countries, 2 (2 \& 3).

[15] Kabir, B.; Bello, A.; Kolo, B. A. \& Bustani, S. A. (2009). Factors inhibiting the growth of local construction firms in Nigeria. ARCOM Conference (pp. 351-359). Nottingham, UK: ARCOM, 7th-9th September.

[16] Ofori, G. (2014). Nature of the construction industry, its needs and its development: A Review of four decades of research. Proceedings of the CIBW107 International Conference, (pp. 28th - 30th January,1019). Lagos, Nigeria. 